history and creative invention over the whole range of life as throughout the whole range of literature. The danger which menaces learning is not that of conflict of sectional interests but of a general relapse into barbarism. It is not needless to reaffirm once more our emphatic and uncompromising support of all efforts to maintain the free development of the human intellect, unhampered by autocratic interference.

\section{Avon Biological Research}

The third Annual Report, 1934-35, describing the continuation of work on the lines approved by the Avon Co-ordinating Committee, has recently been published (University College, Southampton. Avon Biological Research. Annual Report, 1934-35. Pp. $126+3$ plates. Southampton : University College, 1936. $2 s .6 d$.). The work is conducted at University College, Southampton, where there are special laboratories set aside for the purpose, and on various parts of the river ; the main purpose being salmon research and its branches, although trout research is also included. The salmon research is approved by the Development Commissioners, who since October 1934 have kept it under their official supervision, the Treasury having granted a sum towards the expenses enabling, among other things, a junior research officer to be appointed. Much help is acknowledged. Colonel Bennet-Stanford has erected a hatchery and provided facilities for the freshwater rearing of salmon in his lakes at the head waters of the Nadder, a tributary of the Avon, more than fifty miles from the sea, and many others have assisted substantially, both financially or by individual work and advice. A rotating fish screen (described in the appended papers) has been set up on Major Napier's land at Fordingbridge, where also are experimental spawning beds. East Mill still remains the headquarters of the river. The general report deals with the importance of vermin, artificial propagation and smolt migration. Appended papers include "British Mammals and Birds as Enemies of the Atlantic Salmon" (a most interesting and important summary), and "Importance of Iodine in Relation to Fish", besides accounts of hatching and stocking experiments and of scales from the Avon trout and grayling.

\section{Useful Birds}

Three new Advisory Leaflets dealing with some British birds of prey have been issued by the Ministry of Agriculture and Fisheries. One describes the appearance and activities of the buzzard, another those of the long-eared and short-eared owls; and in the case of each of these birds the decision is that it is beneficial and worthy of careful protection. The third leaflet discusses the tawny or brown owl and the little owl; while the former is regarded on the whole as doing more good than harm, the little owl, although it also destroys pests, has become too plentiful in many districts on account of the loss it causes to poultry-keepers and others, and is therefore in no need of protection. These leaflets with their excellent illustrations by G. E. Lodge should be widely distributed in schools; they form the best sort of propaganda for bird protection.

\section{Destruction of 'Vermin' in Bedfordshire}

Luton Museum has performed a useful service in publishing a summary of "Bedfordshire Vermin Payments", extracted by J. Steele Elliot from the records of parish officials during the sixteenth to nineteenth centuries. A recent note in these columns referred to the exceedingly limited distribution of the pinemarten and polecat in Britain at the present day; but up to 1808 the pine-marten was being killed, at $2 d$. a head, in Bedfordshire, and in forty-two parishes payment was claimed on a total of more than 6,000 polecats, the most recent record in these accounts being in $\mathbf{1 8 3 5}$. It is a sorry tale of extermination.

\section{Indian Wild Life : a New Magazine}

IN an effort to encourage wider sympathy with wild life in India, a group of enthusiasts has published Indian Wild Life, the official organ of the All India Conference for the Preservation of Wild Life. The objects of the Conference are ambitious : to give effect in all parts of India to the provisions of the All India Convention of 1935, to encourage the preservation of fauna and flora, popularize natural history in schools, establish a natural history library, and an exchange system of literature, to establish a National Park and to publish books and pamphlets on Indian natural history, and to disseminate literature in different languages. It is a big programme, but it is worth aiming at, and well worth encouraging. To the mind of a Western reader, too great a part of the new magazine is given up to personal paragraphs, but it is encouraging to find that already one of its objects has been fulfilled, and that a United Provinces National Park is an accomplished fact-the only Park of its kind in India.

\section{British School of Archæology at Rome}

IT is announced that Mr. C. A. Ralegh Radford has been appointed director of the British School of Archæology at Rome in succession to Mr. Colin Hardie, recently appointed fellow and classical tutor of Magdalen College, Oxford. Mr. Radford is a former student of the British Schools of Archæology at both Athens and Rome; and by his excavations on prehistoric Roman and medieval sites in Britain and abroad has taken a prominent part in recent advances in archæological studies. He was appointed Inspector of Ancient Monuments for Wales and Monmouthshire in 1929, and is also a member of the Royal Commission on Ancient Monuments of that area. As general secretary with Prof. V. Gordon Childe of the First International Congress of Preand Protohistoric Sciences he was jointly responsible with him for much of the success of the session held in London in 1932. Mr. Radford's training and experience have been such as should enable him to preserve the necessary balance between the studies of the School in prehistoric, protohistoric and classical archæology, to which the special eircumstances of Rome are perhaps less conducive than those of Athens. 